\title{
Development of a Derivative Spectrophotometric Method for the Determination of Fungicide Zinc Ethylenebisdithiocarbamate using Sodium Molybdate
}

\author{
Manpreet Kaur, ${ }^{a}$ Varinder Kaur, ${ }^{a}$ Ashok K. Malik, ${ }^{*, a}$ Neelam Verma, ${ }^{b}$ Baldev Singh ${ }^{a}$ and A. L. J. Rao \\ ${ }^{a}$ Department of Chemistry and ${ }^{b}$ Department of Biotechnology, Punjabi University, Patiala, 147002 Punjab, India
}

\begin{abstract}
Neste trabalho foi desenvolvido um procedimento espectrofotométrico derivativo para a determinação de etilenobisditiocarbamato de zinco(II), Zineb, com base na formação do complexo azul de molibdato de sódio em meio ácido. A lei de Beer é obedecida até $40 \mu \mathrm{g} \mathrm{mL}^{-1}$ de Zineb no

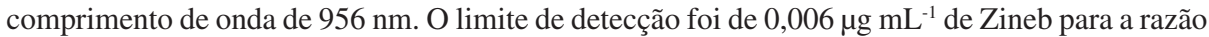
$\mathrm{S} / \mathrm{N}=3$ considerando diversos parâmetros como o efeito da concentração de ácido. A interferência de diversos íons na determinação de Zineb foi avaliada. A maioria dos metais alcalinos e sais metálicos não causou interferências. O procedimento tem boa sensibilidade e foi empregado para a determinação de Zineb em amostras comerciais de alimentos contendo Dithane Z 78 e Hexathane $75 \%$ W.P.. Os resultados foram comparados com procedimentos previamente propostos. Zineb foi determinado com sucesso sem a ocorrência de interferências na presença de outros ditiocarbamatos, tais como Ziram, Thiram, Ferbam etc.
\end{abstract}

A derivative spectrophotometric procedure was developed for the determination of zinc(II) ethylenebisdithiocarbamate, Zineb, after formation of its blue colored complex with sodium

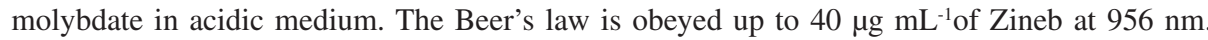
The detection limit was $0.006 \mu \mathrm{g} \mathrm{mL} \mathrm{m}^{-1}$ for Zineb when $\mathrm{S} / \mathrm{N}$ ratio is 3 taking into account various parameters, such as the effect of acid concentration. The interference of a large number of ions on the determination of Zineb was evaluated. Most of the alkaline metals and metal salts did not interfere. The procedure presented proper sensitivity and it was applied for determining Zineb in food stuffs and commercial samples of Dithane Z 78 and Hexathane 75\% W.P.. Results were compared with earlier reported methods. Zineb was successfully determined without any interferences in the presence of other dithiocarbamates like ziram, thiram, ferbam etc.

Keywords: derivative spectrophotometry, Zineb, sodium molybdate, commercial samples

\section{Introduction}

Zineb is a light colored ethylenebisdithiocarbamate (EBDC) fungicide (Figure 1) used to prevent crop damage in the field and to protect the harvested crops from deterioration during storage and transport. It is a non-systemic (surface acting) fungicide, commercially available as wettable powder, dust formulations and also in mixture with other fungicides under trade names like Dithane Z-78, Amitan etc. Like other EBDCs, it also shows strong metal binding properties ${ }^{1,2}$ and hence is capable of blocking enzymes and affecting biological systems. Even the breakdown products of Zineb, viz. ehtylenethiourea (ETU) and ethylene thiuram monosulfide, are quite harmful. The US EPA has classified ETU as a probable

*e-mail: malik_chem2002@yahoo.co.uk human carcinogen. Hence, the residues of Zineb in food and fodder are harmful and can also go through soil and leach into the ground water.

$$
[
$$<smiles>S=C1CC(=S)NCCN1</smiles>

Figure 1. Structure of Zineb.

Many methods like spectrophotometry, ${ }^{1,3-8}$ flame atomic absorption spectrometry ${ }^{9,10}$ FT-IR, ${ }^{11}$ gas chromatography, ${ }^{12,13}$ HPLC,${ }^{14-16}$ polarography, ${ }^{17,18}$ biosensors, ${ }^{19}$ and enzyme linked immuno sorbent assay ${ }^{20}$ are available for Zineb determination and other dithiocarbamates. 
Most of the applied methods use different techniques like spectrophotometry and gas chromatography ${ }^{3}$ based on analysis of $\mathrm{CS}_{2}, \mathrm{H}_{2} \mathrm{~S}$ or amines which are evolved by the decomposition of EBDCs. Dithiocarbamates have been determined in vegetables and food stuffs using HPLC, ${ }^{21}$ extraction voltammetry ${ }^{22}$ and titrimetry. ${ }^{23}$ Dithiocarbamates (DTCs) can also be determined by methods like, iodometry ${ }^{24,25}$ and indirect complexometry ${ }^{26}$ etc. Although, the methods discussed above have various disadvantages, such as methods other then gas chromatography are indirect, time consuming and less sensitive. Gas chromatographic methods are sensitive but suffer from lack of the selectivity since all dithiocarbamate pesticides evolve carbon disulphide on acid hydrolysis. Moreover, the dithiocarbamate decompositions are strongly dependent on temperature and on individual dithiocarbamates. The evolution of $\mathrm{CS}_{2}$ requires more than $2 \mathrm{~h}$ for the decomposition of dithiocarbamate. Additionally, high performance LC methods are relatively expensive and may involve the use of the toxic and expensive solvents. DTCs are also determined using FTIR spectrometry but this method is less sensitive and time consuming. ${ }^{27}$

In the work here described, a relatively fast, simple, sensitive and selective derivative spectrophotometric method is presented for the analysis of Zineb by converting it into a molybdenum complex. Zineb reacts with sodium molybdate under heating to form a blue colored complex. Zineb and sodium molybdate formed a 1:2 complex. Zineb releases $\mathrm{Zn}^{2+}$ and its dithiocarbamate unit, the latter forms a complex with sodium molybdate which is then extracted into methyl isobutyl ketone (MIBK) and determined by derivative spectrophotometry. The significant advantage of this method compared to the gas chromatographic methods is that it can be applied for the direct determination of Zineb in the presence of other dithiocarbamates like Ziram, Thiram and Ferbam.

\section{Materials and Methods}

\section{Equipment and reagents}

An Elico SL-164, double beam UV-Vis spectrophotometer was used. Zineb standard was obtained from Riedel de Haën, Germany. A stock solution was prepared by dissolving $100 \mathrm{mg}$ of Zineb in $100 \mathrm{~mL}$ of $0.1 \mathrm{~mol} \mathrm{~L}^{-1} \mathrm{NaOH}$. Further dilutions were carried out with $0.1 \mathrm{~mol} \mathrm{~L}^{-1} \mathrm{NaOH}$ as required. A $2 \% \mathrm{~m} / \mathrm{v}$ solution of sodium molybdate was prepared in doubly distilled water.

\section{Absorption spectra}

A volume of $2 \mathrm{~mL}$ of $2 \% \mathrm{~m} / \mathrm{v}$ sodium molybdate solution and $1 \mathrm{~mL}$ of $2 \mathrm{~mol} \mathrm{~L}^{-1} \mathrm{H}_{2} \mathrm{SO}_{4}$ were added to an aliquot containing $100 \mu \mathrm{g}$ of Zineb. The mixture was boiled for $5 \mathrm{~min}$, cooled and water was added to make the volume up to $5 \mathrm{~mL}$. The blue complex formed was extracted after shaking into $5 \mathrm{~mL}$ of MIBK (methyl isobutyl ketone). The organic layer was collected into a test tube containing fused $\mathrm{CaCl}_{2}$ to remove any moisture. The suspension was then decanted into a $1 \mathrm{~cm}$ cell and the spectrum was taken against a reagent blank. The molybdenum complex shows peaks at $670 \mathrm{~nm}$ and $956 \mathrm{~nm}$ (Figure 2), but the peak at $956 \mathrm{~nm}$ has much higher absorbance; hence all the measurements were made at this wavelength. The first derivative, second derivative, third derivative and fourth derivative curves were given in Figures 3-6 respectively.

In Derivative Spectrophotometry, DS, the wavelength reproducibility and signal to noise ratio are quite important. The features like peak height and noise level depend on parameters chosen like order of derivative, scan speed and integration time during recording of spectra. The use of optimum parameter will give better resolution

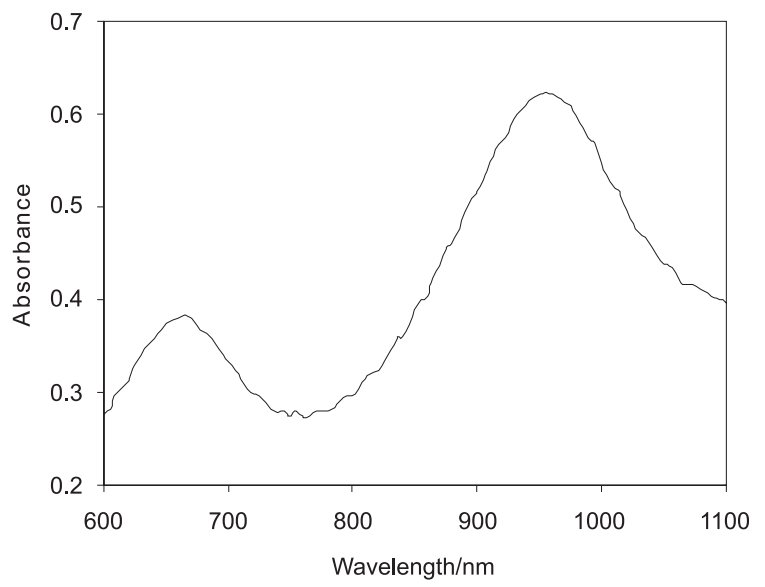

Figure 2. Absorption spectrum of molybdenum ehtylenebisdithiocarbamate complex: Zineb $(2 \mathrm{~mL})$ with sodium molybdate $(2 \% \mathrm{~m} / \mathrm{v})$ in presence of $\mathrm{H}_{2} \mathrm{SO}_{4}\left(2 \mathrm{~mol} \mathrm{~L}^{-1}\right)$, extracted with MIBK compared to a reagent blank.

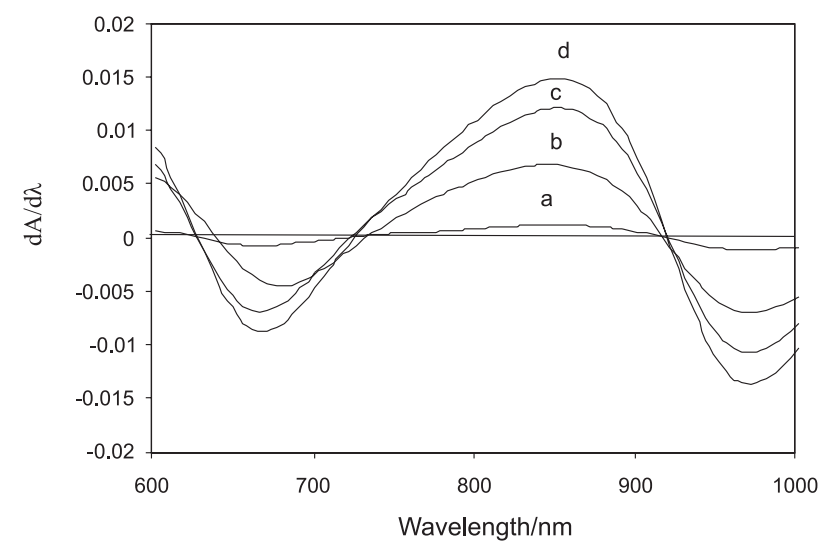

Figure 3. $1^{\text {st }}$ derivative curves of molybdenum-ethylenebisdithiocarbamate complex: a, b, c, d representing the amount of Zineb in final solutions (a: 2, b: 10, c: 20, d: 40 , all values in $\mu \mathrm{g} \mathrm{mL}^{-1}$ ). 


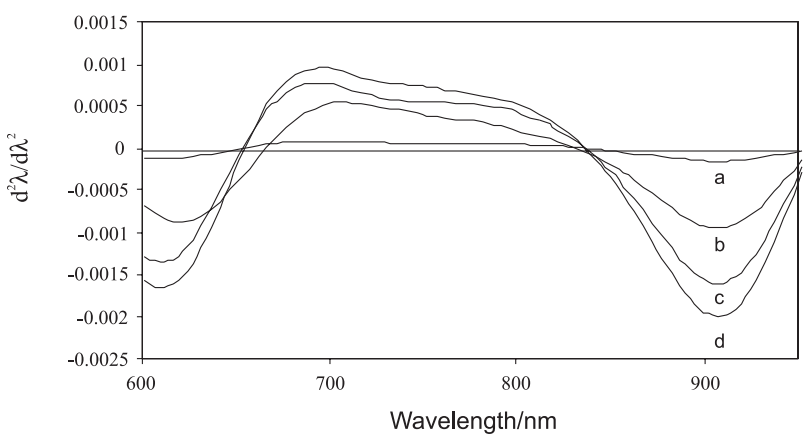

Figure 4. $2^{\text {nd }}$ derivative curves of molybdenum-ethylenebisdithiocarbamate complex: a, b, c, d representing the amount of Zineb in final solutions (a: 2 , b: 10, c: 20, d: 40, all values in $\mu \mathrm{g} \mathrm{mL}^{-1}$ ).

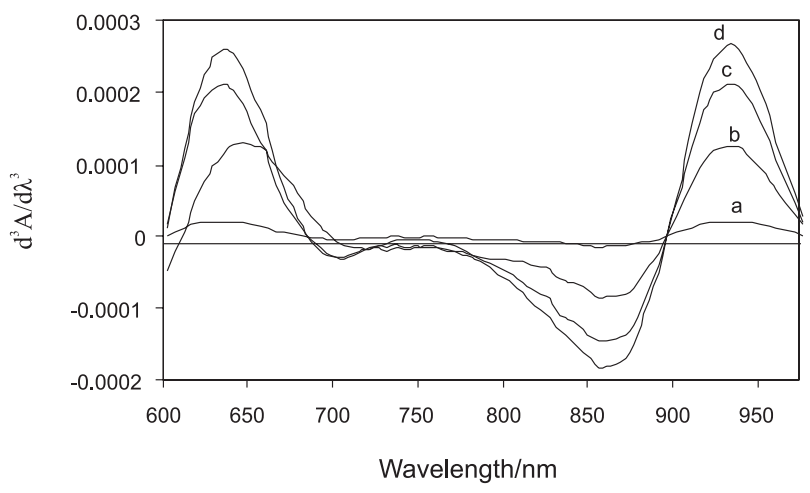

Figure 5. $3^{\text {rd }}$ derivative curves of molybdenum-ethylenebisdithiocarbamate complex: a, b, c, d representing the amount of Zineb in final solutions (a: 2 , b: 10, c: 20, d: 40, all values in $\mu \mathrm{g} \mathrm{mL}^{-1}$ ).

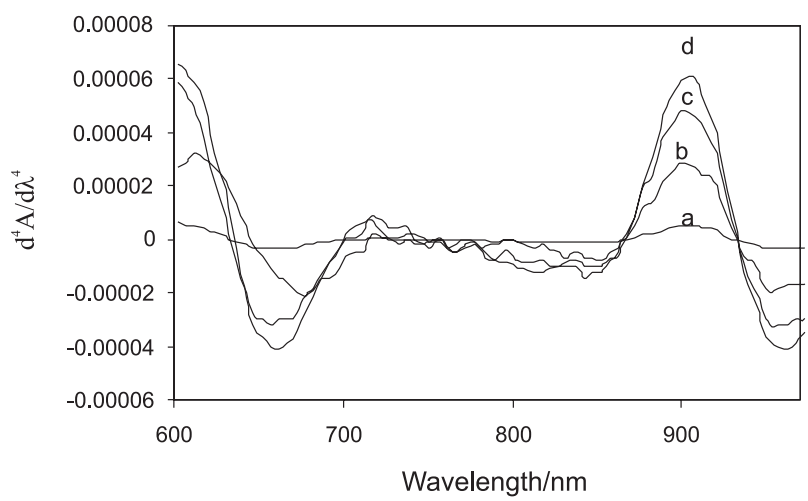

Figure 6. 4th derivative curves of molybdenum-ethylenebisdithiocarbamate complex: a, b, c, d representing the amount of Zineb in final solutions (a: 2 , b: 10, c: 20, d: 40, all values in $\mu \mathrm{g} \mathrm{mL}^{-1}$ ).

and improved sensitivity. For the $4^{\text {th }}$ derivative spectra, $\Delta \lambda=9 \mathrm{~nm}$ was found to be ideal.

\section{Preparation of calibration curve}

Solutions containing from 10 to $250 \mu \mathrm{g}$ of Zineb were analysed applying the proposed procedure and the derivative spectra were obtained against a reagent blank prepared under similar conditions. The characteristics of zero order and derivative spectra are summarized in Tables 1 and 2 .

Table 1. Different parameters of zero order spectrum

\begin{tabular}{|c|c|c|}
\hline Sample No. & Parameter & $\begin{array}{c}\text { Zero derivative spectrum of } \\
\text { Zineb-sodium molybdate } \\
\text { complex }\end{array}$ \\
\hline 1 & $\begin{array}{l}\text { molar absorptivity/ } \\
\left(\mathrm{L} \mathrm{mol}^{-1} \mathrm{~cm}^{-1}\right)\end{array}$ & $1.4 \times 10^{4}$ \\
\hline 2 & $\begin{array}{l}\text { specific absorptivity/ } \\
\quad\left(\mathrm{mL} \mathrm{g}^{-1} \mathrm{~cm}^{-1}\right)\end{array}$ & 35.2 \\
\hline 3 & $\begin{array}{l}\text { Sandell's sensitivity/ } \\
\qquad\left(\mu \mathrm{g} \mathrm{mL} \mathrm{L}^{-1}\right)\end{array}$ & $2.84 \times 10^{-2}$ \\
\hline 4 & $\begin{array}{l}\text { analytical sensitivity/ } \\
\left(\mu \mathrm{g} \mathrm{mL} \mathrm{L}^{-1}\right)\end{array}$ & $2.80 \times 10^{-2}$ \\
\hline 5 & linear range $/\left(\mu \mathrm{g} \mathrm{mL}^{-1}\right)$ & 2 to 40 \\
\hline
\end{tabular}

\section{Results and Discussion}

\section{Beer's law and sensitivity}

The optimum wavelength interval was found to be $9 \mathrm{~nm}$ for improve both resolution and sensitivity. The wavelength range to obtain the spectra was selected from 600 to $1100 \mathrm{~nm}$. The calibration curve was obtained by measuring the peak height between wavelengths from 850 to $938 \mathrm{~nm}$. Absorbance of sodium molybdate complex with Zineb recorded against a reagent blank was linear over a concentration range from 2 to $40 \mu \mathrm{g} \mathrm{mL}^{-1}$. The estimated detection limit is $0.006 \mu \mathrm{g} \mathrm{mL}^{-1}$ for Zineb when $\mathrm{S} / \mathrm{N}$ ratio was 3 .

\section{Effect of heating time}

It was observed that the absorbance of the complex increased up to certain extent when heating time was also increased. Therefore, the reaction mixture was heated in different intervals of time. It was observed that a $5 \mathrm{~min}$ heating time was enough to obtain maximum absorbance. Increasing the heating time beyond this did not increase the absorbance showing that complete complex formation was achieved.

\section{Effect of acid concentration}

Maximum absorbance was observed when acid volume added varied from 1 to $1.5 \mathrm{~mL}$. Greater acid volumes caused a decrease in absorbance signals, thus higher acid concentrations did not improve the complex formation. 
Table 2. Comparison of calibration curves of Zineb using different derivative spectra

\begin{tabular}{|c|c|c|c|c|c|c|c|c|}
\hline Zineb complex & $\begin{array}{c}\text { Order of } \\
\text { derivative }\end{array}$ & $\lambda / \mathrm{nm}$ & Regression equation & $\mathrm{R}^{2}$ & $\operatorname{RSD}(\%)$ & SD of slope & SD of intercept & $\begin{array}{l}\text { Analytical sensitivity/ } \\
\qquad\left(\mu \mathrm{g} \mathrm{mL} \mathrm{mL}^{-1}\right)\end{array}$ \\
\hline 1 & $1^{\mathrm{st}}$ & 852 & $y=6 \times 10^{-5} x+0.007$ & 0.9997 & \pm 1.9 & $1.01 \times 10^{-6}$ & $1.4 \times 10^{-4}$ & 1.20 \\
\hline 2 & $2^{\text {nd }}$ & 907 & $y=6 \times 10^{-6} x+0.009$ & 0.9937 & \pm 1.5 & $8.16 \times 10^{-8}$ & $1.6 \times 10^{-4}$ & 0.16 \\
\hline 3 & $3^{\text {rd }}$ & 937 & $y=8 \times 10^{-7} x+9 \times 10^{-5}$ & 0.9992 & \pm 1.9 & $8.16 \times 10^{-9}$ & $8.16 \times 10^{-7}$ & 0.20 \\
\hline 4 & $4^{\text {th }}$ & 902 & $y=3 \times 10^{-7} x-9 \times 10^{-6}$ & 0.9994 & \pm 1.3 & $5.03 \times 10^{-9}$ & $8.16 \times 10^{-8}$ & 0.006 \\
\hline
\end{tabular}

\section{Effect of other ions}

Sample solutions containing $5 \mu \mathrm{g} \mathrm{mL} \mathrm{m}^{-1}$ of Zineb and various amounts of different alkaline metal salts or metal ions were prepared and the general procedure was applied. It was observed that the addition of the following foreign anions did not interfere in the determination of Zineb: bromide $(11 \mathrm{mg})$, acetate $(15 \mathrm{mg})$, chloride $(3.5 \mathrm{mg})$, fluoride $(2 \mathrm{mg})$, citrate $(20 \mathrm{mg})$ and EDTA $(0.06 \mathrm{mg})$. Among the metal ions examined, $\mathrm{Zn}(\mathrm{II})$ $(0.066 \mathrm{mg}), \mathrm{Mo}(\mathrm{IV})(0.14 \mathrm{mg}), \mathrm{Ni}(\mathrm{II})(0.30 \mathrm{mg}), \mathrm{Co}(\mathrm{II})$ $(0.009 \mathrm{mg})$ did not interfere. It was clear that several ions like $\mathrm{Fe}(\mathrm{II}$ and III), $\mathrm{Mn}(\mathrm{II}), \mathrm{Hg}(\mathrm{II})$, interfered in Zineb determination. Therefore, $1 \mathrm{~mL}$ of $5 \% \mathrm{~m} / \mathrm{v} \mathrm{NaF}$ solution was used to mask $\mathrm{Fe}$ (II) and $\mathrm{Fe}$ (III) ions whereas $2 \mathrm{~mL}$ of $5 \% \mathrm{~m} / \mathrm{v}$ sodium citrate was used to mask $\mathrm{Hg}$ (II) and $\mathrm{Cu}(\mathrm{II})$. Manganese(II) was masked by adding $1.5 \mathrm{~mL}$ of $1 \% \mathrm{~m} / \mathrm{v}$ potassium bromide solution.

\section{Effect of standing time}

It was observed that the solution absorbance became constant after 2-3 min. So, after extracting into MIBK, a 5 min standing time was selected. The absorbance of the complex remained practically constant for about
30 min with absorbance RSD values varying from 0.69 to $1.6 \%(\mathrm{n}=3)$ at analytes concentrations between 2 to $40 \mu \mathrm{g} \mathrm{mL} \mathrm{m}^{-1}$.

\section{Applications}

Determination of Zineb in fortified samples of wheat grains, cabbage and rice

The developed procedure was applied to the determination of Zineb in fortified samples of wheat grains, cabbage and rice. A mass of $20 \mathrm{~g}$ of the foodstuff was finely crushed and a solution containing a known amount of Zineb was added and mechanically shaken with $100 \mathrm{~mL}$ of ACN acetonitrile, ACN, for $1 \mathrm{~h}$. This mixture was filtered and the residue was washed with $3 \times 10 \mathrm{~mL}$ portions of ACN. The extracts were evaporated in a water bath $\left(70-90{ }^{\circ} \mathrm{C}\right)$. Residual solvent were removed using a current of dry air. The Zineb content in the residue was determined using the developed procedure and the results indicated good recoveries in all cases (Table 3 ).

\section{Determination of Zineb in commercial samples}

The method was applied for determination of Zineb in commercial samples, Dithane Z 78 and Hexathane $75 \%$ W.P. The formulated product sample solutions were

Table 3. Determination of Zineb in fortified samples (mean values and standard deviations, $n=5$ )

\begin{tabular}{|c|c|c|c|c|c|c|}
\hline \multirow{2}{*}{ Sample } & \multirow{2}{*}{ Crop } & \multirow{2}{*}{ Zineb Added $/(\mu \mathrm{g})$} & \multirow{2}{*}{ Zineb Found/( $\mu \mathrm{g})$} & \multirow{2}{*}{ Recovery $(\%) \pm \operatorname{RSD}(\%)$} & \multicolumn{2}{|c|}{ Rangaswamy et al. ${ }^{30}$ method } \\
\hline & & & & & Zineb found $/(\mu \mathrm{g})$ & Recovery (\%) \\
\hline \multirow[t]{9}{*}{ Zineb } & Wheat & 10 & 9.7 & $97.0 \pm 2.4$ & 9.6 & 96.0 \\
\hline & & 15 & 14.8 & $98.6 \pm 2.3$ & 14.7 & 98.0 \\
\hline & & 20 & 19.8 & $99.0 \pm 1.9$ & 19.8 & 99.0 \\
\hline & Rice & 8 & 7.8 & $97.5 \pm 2.5$ & 7.6 & 95.0 \\
\hline & & 10 & 9.9 & $99.0 \pm 2.3$ & 9.6 & 96.0 \\
\hline & & 12 & 11.8 & $98.3 \pm 2.2$ & 11.6 & 96.6 \\
\hline & Cabbage & 12 & 11.8 & $98.3 \pm 2.3$ & 11.7 & 97.5 \\
\hline & & 14 & 13.8 & $98.5 \pm 2.4$ & 13.7 & 97.8 \\
\hline & & 18 & 18.1 & $100.5 \pm 2.2$ & 17.6 & 97.8 \\
\hline
\end{tabular}

Sample mass: $10 \mathrm{~g}$. 
Table 4. Determination of Zineb in commercial samples (mean values and standard deviations, $\mathrm{n}=5$ )

\begin{tabular}{|c|c|c|c|c|c|}
\hline \multirow{2}{*}{ Commercial Samples } & \multirow{2}{*}{ Zineb taken/( $\mu \mathrm{g})$} & \multirow{2}{*}{ Zineb found $/(\mu \mathrm{g})$} & \multirow{2}{*}{$\operatorname{RSD}(\%)$} & \multicolumn{2}{|c|}{ Rangaswamy et al. ${ }^{30}$ method } \\
\hline & & & & Zineb found $/(\mu \mathrm{g})$ & Recovery (\%) \\
\hline \multirow[t]{2}{*}{ Dithane Z-78 } & 8 & 7.7 & 2.1 & 7.6 & 95.0 \\
\hline & 20 & 19.9 & 2.3 & 19.8 & 99.0 \\
\hline Hexathane & 5 & 4.9 & 1.9 & 4.7 & 94.0 \\
\hline $75 \%$ W.P. & 15 & 15.1 & 2.2 & 14.6 & 97.3 \\
\hline
\end{tabular}

Table 5. Determination of Zineb and Ziram in synthetic mixtures (mean values and standard deviations, $\mathrm{n}=5$ )

\begin{tabular}{|c|c|c|c|c|c|}
\hline \multirow{2}{*}{ Zineb added $/(\mu \mathrm{g})$} & \multirow{2}{*}{ Ziram added $/(\mu \mathrm{g})$} & \multirow{2}{*}{ Zineb found/( $\mu \mathrm{g})$} & \multirow{2}{*}{ Ziram found/( $\mu \mathrm{g})$} & \multicolumn{2}{|c|}{ Recovery $(\%) \pm \operatorname{RSD}(\%)$} \\
\hline & & & & Zineb & Ziram \\
\hline 60 & 40 & 59.0 & 39.5 & $98.3 \pm 2.3$ & $98.7 \pm 2.7$ \\
\hline 50 & 50 & 49.7 & 49.0 & $99.4 \pm 2.8$ & $98.0 \pm 2.5$ \\
\hline 30 & 70 & 29.5 & 69.5 & $98.3 \pm 3.1$ & $99.3 \pm 2.4$ \\
\hline
\end{tabular}

prepared as discussed earlier and determined using the proposed procedure. Results are presented in Table 4.

\section{Sequential determination of Zineb and Ziram in synthetic mixtures}

The procedure was applied for the simultaneous determination of Ziram and Zineb in synthetic mixtures. Ziram forms a yellow complex with sodium molybdate in cold solution which absorbs at $420 \mathrm{~nm}^{28}$, whereas Zineb forms complex under heating, all other conditions remaining the same. Synthetic mixtures of Zineb and Ziram were made in different proportions. To the binary mixture, $0.15 \mathrm{~mL}$ of $2 \mathrm{~mol} \mathrm{~L}^{-1} \mathrm{H}_{2} \mathrm{SO}_{4}$ and $2 \mathrm{~mL}$ of $2 \% \mathrm{~m} / \mathrm{v}$ sodium molybdate were added. Molybdenum-Ziram complex was extracted into a volume of $5 \mathrm{~mL}$ MIBK and Zineb remained in aqueous phase. The absorbance of Ziram-molybdenum complex was measured at $420 \mathrm{~nm}$. Afterwards, it was added $1 \mathrm{~mL} 4 \mathrm{~mol}$ $\mathrm{L}^{-1} \mathrm{H}_{2} \mathrm{SO}_{4}$ and $2 \mathrm{~mL}$ of $2 \% \mathrm{~m} / \mathrm{v}$ sodium molybdate solution to the aqueous phase containing Zineb. This solution was boiled for $5 \mathrm{~min}$, cooled and extracted into $5 \mathrm{~mL}$ MIBK. The spectrum of blue complex of Zineb was taken between 600 and $1100 \mathrm{~nm}$. Ziram was determined from the standard calibration curve..$^{28}$ Results are shown in Table 5.

\section{Conclusions}

The proposed procedure is more sensitive than the carbon disulphide evolution methods. Using this procedure $0.006 \mu \mathrm{g} \mathrm{mL}^{-1}$ of Zineb can be determined which is equivalent to $0.0033 \mu \mathrm{g} \mathrm{mL}^{-1}$ of evolved carbon disulphide. Additionally, direct sequential determination of Ziram and Zineb is also possible. The sensitivity of the present procedure is comparable to other spectrophotometric methods, however its selectivity was better (Table 6). This comment is in disagreement with the remark pointed out in Table 6. The broad applicability of this method makes it suitable for dithiocarbamate analysis in foodstuffs and in commercial samples.

Table 6. Molar absorptivities of Zineb complexes

\begin{tabular}{|c|c|c|c|}
\hline Procedure & $\begin{array}{l}\text { Molar absorptivity/ } \\
\left(\mathrm{L} \mathrm{mol}^{-1} \mathrm{~cm}^{-1}\right)\end{array}$ & Remarks & Reference \\
\hline Cupric acetate & Not reported & $\begin{array}{l}\text { Low sensitivity, long } \\
\text { tedious procedure }\end{array}$ & 30 \\
\hline Molybdenum & $0.62 \times 10^{4}$ & Less sensitive & 28 \\
\hline Phenylfluorone + Cetylpyridinium bromide & $6.9 \times 10^{4}$ & Selective and sensitive & 31 \\
\hline 1-(2-Pyridylazo)-2-naphthol & $5.06 \times 10^{4}$ & $\begin{array}{c}\text { Column pre-concentration } \\
\text { is required }\end{array}$ & 29,32 \\
\hline Molybdenum (at $956 \mathrm{~nm}$ ) and derivative spectrophotometry & $1.4 \times 10^{4}$ & $\begin{array}{l}\text { Similar molar absorptivity } \\
\text { and improved selectivity }\end{array}$ & This work \\
\hline
\end{tabular}




\section{References}

1. Mehta, S. K.; Malik, A. K.; Singh, B.; Rao, A. L. J.; Talanta 2005, 67, 725 .

2. Malik, A. K.; Camara, C. In Encyclopedia of Agrochemicals; Plimmer, J. R.; Gamon D. W.; Ragsdale, N. N., eds.; John Wiley: New York, 2003, vol. 1.

3. Kesari, R; Gupta, V. K.; Talanta 1998, 45, 1097.

4. Agarwal, V.; Shivhare, P.; Gupta, V. K.; Fresenius J. Anal. Chem. 1992, 344, 350.

5. Rao, A. L. J.; Verma, N.; Talanta 1989, 36, 1041.

6. Walsh, M. I.; Belal, F.; Metwally, M. E.; Hefnawy, M. M.; Food Chem. 1993, 47, 411.

7. Malik, A. K.; Rao, A. L. J.; Talanta 1991, 38, 941.

8. Kapoor, J.; Rao, A. L. J.; Pestic. Sci. 1994, 42, 109.

9. Baena, J. R.; Gallego, M.; Valcárcel, M.; Analyst 2000, 125, 1495.

10. Cassella, R. J.; Salim, V.A.; Garrigues, S.; Santelli, R. E.; de la Guardia, M.; Anal. Sci. 2002,18, 1253.

11. Cassella, A. R.; Cassella, R. J.; Garrigues, S.; Santelli, R.E.; de Campos, R. C.; de la Guardia, M.; Analyst 2000, 125, 1829.

12. Maini, P.; Boni, R.; Bull. Environ. Contam. Toxicol. 1986, 37, 931.

13. Friedrichs, K.; Winkeler, H. D.; Gerhards, P.; Z. Lebensm. Unters. Forsch. 1995, 201, 69.

14. Bardarov, V.; Zaikov, C.; Mitewa, M.; J. Chromatogr. 1989, 479, 97.

15. Weissmahr, K. W; Houghton, C. L; Sedlak, D. L.; Anal Chem. 1998, 70, 4800.

16. Nakazawa, H.; Tsuda, Y.; Ito, K.; Yoshimura, Y.; Kuba, H.; Homma, H.; J. Liq. Chromatogr. Rel. Technol. 2004, 27, 705.
17. Malik, A. K.; Rao, A. L. J.; J. Indian Chem. Soc. 1998, 75, 491.

18. Lin, M. S.; Jan, B. I.; Leu, H. J.; Lin, J. S.; Anal. Chim. Acta 1999, 388, 111.

19. Noguer, T.; Gradinaru, A.; Ciucu, A.; Marty, J. L.; Anal. Lett. 1999, 32, 1723.

20. Gueguen, F.; Boisdé, F.; Queffelec, A. L.; Haelters, J. P.; Thouvenot, D.; Corbel, B.; Nodet, P.; J. Agric. Food Chem. 2000, 48, 4492.

21. Malik, A. K.; Rao, A. L. J.; J. Agric. Food Chem. 2000, 48, 4044.

22. Ulakhovich, N. A.; Medyantseva, E. P.; Frolova, V. P.; Romanova, O. N.; Zh. Anal. Khim. 1983, 38, 1963.

23. Verma, B. C.; Sidhu, H. S.; Sood, R. K.; Talanta 1982, 29 , 703.

24. Grand, A. F.; Tamres, M.; Anal. Chem. 1968, 40, 1904.

25. Clyde, D. D.;. J. Assoc. Off. Anal. Chem. 1983, 66, 646.

26. Hyman A. S.; Analyst 1969, 94, 152.

27. Malik, A. K.; Rao, A. L. J.; Talanta 1990, 37, 1205.

28. Rao, A.L. J.; Verma, N.; J. Inst. Chemists (India) 1988, 60, 5.

29. Rao, A. L. J.; Malik, A. K.; Kapoor, J.; Talanta 1993, 40, 201.

30. Rangaswamy, J. R.; Poornima, P.; Majumdar,S. K.; J. Assoc. Off. Anal. Chem. 1971, 54, 1120.

31. Malik, A. K.; Kapoor, J.; Rao, A. L. J.; J. Environ. Monit. 2000, 2, 367 .

32. Malik, A. K.; Sharma, V.; Sharma, V. K.; Rao, A. L. J.; J. Agric. Food Chem. 2004, 52, 7763.

Received: June 11, 2008

Web Release Date: March 31, 2009 